\title{
Pengolahan buah salak Bangkalan untuk mengembangkan potensi lokal
}

\author{
Putri Ulfa Kamalia $^{1 *}$, Rochmawati ${ }^{2}$, Adin Novitasari ${ }^{3}$, Febrina Iqhyanul \\ Imansari ${ }^{4}$, Mila Hariyanti ${ }^{5}$ \\ ${ }^{1}$ Universitas Negeri Surabaya, Surabaya, Indonesia, email: putrikamalia@unesa.ac.id \\ 2Universitas Negeri Surabaya, Surabaya, Indonesia, email: rochmawati@unesa.ac.id \\ ${ }^{3}$ Universitas Negeri Surabaya, Surabaya, Indonesia, adinnovita10@gmail.com \\ ${ }^{4}$ Universitas Negeri Surabaya, Surabaya, Indonesia, email: feb.inabastian@gmail.com \\ ${ }^{5}$ Universitas Negeri Surabaya, Surabaya, Indonesia, email: milahariyanti13@gmail.com \\ *Koresponden penulis
}

\begin{tabular}{|c|c|}
\hline Info Artikel & Abstract \\
\hline $\begin{array}{l}\text { Diajukan: 2021-07-06 } \\
\text { Diterima: 2021-11-23 } \\
\text { Diterbitkan: 2021-12-14 } \\
\text { Keywords: } \\
\text { local opportunity; salak of } \\
\text { Bangkalan; processed items } \\
\text { Kata Kunci: } \\
\text { potensi lokal; salak } \\
\text { Bangkalan; produk olahan }\end{array}$ & $\begin{array}{l}\text { Salak is the unofficial mascot of the Bangkalan regency. To promote } \\
\text { salak fruit as a local opportunity, we trained young housewives in } \\
\text { Durinan Village in salak fruit processing, giving them with the essential } \\
\text { skills and knowledge to start a salak fruit processing business. The } \\
\text { activities are divided into five stages: 1) socialisation with the } \\
\text { community; 2) acquisition of materials and tools; 3) training; 4) help; } \\
\text { and 5) programme evaluation. The findings obtained are compatible } \\
\text { with the planned outcome, which is to strengthen the target group's } \\
\text { capacity for salak fruit processing. Among the processed items are } \\
\text { salak donuts, salak ice cream, salak brownies, and salak peel } \\
\text { calligraphy. The project's sustainability potential is the construction of } \\
\text { a business centre for processing Bangkalan salak fruit items into } \\
\text { popular Bangkalan souvenirs. }\end{array}$ \\
\hline & Abstrak \\
\hline $\begin{array}{l}\text { (c) (1) () } \\
\text { Lisensi : cc-by-sa } \\
\text { Copyright @ Putri Ulfa Kamalia, } \\
\text { Rochmawati, Adin Novitasari, Febrina } \\
\text { lqhyanul Imansari, Mila Hariyanti }\end{array}$ & $\begin{array}{l}\text { Salak merupakan ikon Kabupaten Bangkalan. Untuk mempromosikan } \\
\text { buah salak sebagai potensi lokal daerah, kami mengadakan pelatihan } \\
\text { pengolahan buah salak untuk para ibu rumah tangga muda agar } \\
\text { mereka memiliki keterampilan dan mampu untuk membuka usaha } \\
\text { olahan buah salak. Metode pelaksanaan kegiatan dilakukan melalui } \\
\text { beberapa tahap yaitu: 1) Tahap sosialisasi kepada masyarakat; 2) } \\
\text { Tahap perolehan bahan dan alat; 3) Tahap pelatihan; 4) Tahap } \\
\text { pendampingan serta 5) Tahap evaluasi program. Hasil yang telah } \\
\text { dicapai sesuai dengan luaran yang ditargetkan yaitu peningkatan } \\
\text { keterampilan pengolahan buah salak pada kelompok sasaran. Produk } \\
\text { olahan yang dihasilkan berupa donat salak, es krim salak, brownies } \\
\text { salak, dan kaligrafi dari kulit salak. Potensi keberlanjutan darikegiatan } \\
\text { ini adalah terbentuknya sentra usaha produk olahan buah salak } \\
\text { Bangkalan sehingga bisa menjadi oleh-oleh khas Bangkalan yang } \\
\text { diminati wisatawan. }\end{array}$ \\
\hline
\end{tabular}

Cara mensitasi artikel:

Kamalia, P. U., Rochmawati, Novitasari, A., Imansari, F. I., \& Hariyanti, M. (2022). Pengolahan buah salak Bangkalan untuk mengembangkan potensi lokal. Jurnal Inovasi Hasil Pengabdian Masyarakat (JIPEMAS), 5(1), $11-21$. https://doi.org/10.33474/jipemas.v5i1.11439 


\section{PENDAHULUAN}

Sejak beroperasinya Jembatan Suramadu, tiap harinya ribuan kendaraan melintasi Bangkalan karena merupakan gerbang Madura. Wisatawan domestik maupun mancanegara pun berdatangan. Wisatawan yang berkunjung ke Bangkalan selain untuk menikmati keindahan alam, peninggalan sejarah dan juga tidak lupa untuk mengunjungi wisata kulinernya. Sehingga, wisata kuliner di Bangkalan tumbuh dengan pesat. Namun, mungkin banyak yang belum mengetahui bahwa Bangkalan merupakan Kota Salak. Buah salak yang ada di Bangkalan memiliki cita rasa yang khas. Berbeda dengan jenis Salak Pondoh yang rasanya manis, Salak Bangkalan memiliki rasa asam dan manis bercampur menjadi satu. Buah salak Bangkalan memiliki kekhasan tersendiri dibandingkan dengan jenis salak lainnya, yaitu memiliki warna daging buah kuning kecoklatan, rasanya manis sepat, tekstur buah tidak masir, kandungan air lebih banyak dibandingkan dengan jenis salak lainnya, sehingga apabila dikonsumsi akan terasa lebih segar (Dedin Finatsiyatull Rosida \& Taqwa, 2019).

Sejatinya setiap kecamatan di Bangkalan banyak ditumbuhi oleh tanaman salak. Tidak terkecuali di Daerah Durinan, Bangkalan. Durinan merupakan sebuah daerah perkampungan yang terletak di Kecamatan Bangkalan, Kabupaten Bangkalan. Daerah tersebut dinamakan Durinan karena di daerah perkampungan tersebut terdapat banyak duri. Yang dimaksud duri disini adalah duri dari tumbuhan salak. Sehingga hampir di setiap rumah terdapat tumbuhan salak. Maka dari itu, diperlukan suatu program untuk mempromosikan potensi lokal daerah, yakni buah Salak Bangkalan. Sehingga nantinya akan tercipta integrasi kegiatan budidaya, pengolahan, serta pemasaran melalui kegiatan wisata dengan konsep agroedutourism (Cahyani, 2017).

Mata pencaharian masyarakat di Kampung Durinan beragam. Pada awalnya, sebagian besar bermata pencaharian sebagai petani dan nelayan. Namun, seiring dengan perkembangan waktu, mulai banyak masyarakatnya yang bermata pencaharian sebagai pedagang dan PNS. Namun, kebanyakan para wanita berprofesi sebagai ibu rumah tangga. Sedangkan para remaja wanita di Kampung Durinan juga banyak yang menikah di usia muda dan mereka memiliki banyak waktu senggang karena minimnya aktivitas. Padahal di halaman rumah warga Durinan hampir sebagian besar ditanami buah salak namun tidak termanfaatkan dengan baik. Mereka hanya menjualnya ke pasar tanpa diolah terlebih dahulu sehingga harganya cukup murah di pasaran. Maka dari itu, kami ingin mengadakan pelatihan pengolahan buah salak agar mereka memiliki keterampilan dan tertarik untuk membuka usaha sendiri dari potensi yang ada. Sehingga nantinya, mereka dapat berdikari dalam perekonomian keluarganya.

Berawal dengan lebih peka melihat keadaan sekitar, didapatkan kenyataan bahwa banyak buah salak busuk tanpa dimanfaatkan. Setelah kami sempat berkeliling, ditemukan juga banyak salak yang sudah masak berjatuhan dari pohonnya dan hal itu dibiarkan oleh pemiliknya. Bahkan, hal ini nyata sekali terjadi ketika kami tengah berbelanja di pasar tradisional, tiba-tiba ada penjual buah membagi-bagikan buah salak secara cuma-cuma kepada setiap orang yang ditemuinya di pasar. Tidak tanggung-tanggung, penjual buah tersebut 
memberikan satu plastik besar berisi buah salak. Hal ini disebabkan karena buah salak tersebut tidak laku di pasaran dan sebentar lagi akan membusuk. Kerusakan utama buah salak di Indonesia adalah karena memar akibat sistem penanganan pascapanen yang buruk (Ahmad et al., 2001).

Berdasarkan fenomena tersebut, sungguh disayangkan apabila buah salak yang menjadi ikon Kabupaten Bangkalan menjadi tidak bernilai dan tidak dapat bersaing dengan buah-buah lainnya di pasaran. Miris sekali melihat kenyataan ketika buah salak yang ada sangatlah melimpah namun harga pasarnya anjlok. Maka dari itu, diperlukan penanganan lebih lanjut agar salak tidak sampai dibuang percuma yakni melalui kegiatan pengolahan hasil komoditas salak menjadi produk olahan makanan yang lebih tahan lama dan memiliki nilai jual tinggi (Triastuti \& Priyanti, 2017). Solusi yang dilakukan adalah peningkatan nilai tambah buah salak dan peningkatan keterampilan dalam pengelolaan pasca panen salak (Setiawan \& Dewi, 2016).

Pengolahan buah salak sangatlah banyak memberikan manfaat. Hasil penelitian Hapsari et al. (2008) menunjukkan bahwa produksi dodol, manisan dan keripik salak menciptakan nilai tambah sebesar masing-masing $\mathrm{Rp}$ $6.234,65 / \mathrm{kg}$, Rp10.443,23/kg dan Rp 2.297,33/kg. Selain itu, pengolahan salak menjadi dodol salak dapat memberikan banyak keuntungan seperti diversifikasi hasil olahan buah, memberi nilai tambah pada buah, memperpanjang waktu penyimpanan, serta meningkatkan penampilan dan kualitas produk (Suarya et al., 2007). Selanjutnya, hasil penelitian yang dilakukan Lubis et al. (2017) menyatakan bahwa industri pengolahan salak UD. Salacca memiliki keuntungan yang memuaskan, pangsa pasar produknya yang luas bahkan sampai ke Dubai, lokasi yang strategis, kualitas produk yang baik dan dapat meningkatkan kesejahteraan masyarakat desa Parsalakan sehingga industri pengolahan UD. Salacca ini memiliki prospek dan layak untuk dikembangkan lagi di masa yang akan datang.

Berdasarkan permasalahan yang terjadi, kami mengadakan suatu kegiatan pelatihan kepada masyarakat dengan mengolah buah Salak Bangkalan sebagai bahan baku utamanya. Tujuan dari diadakan pelatihan ini adalah untuk mengembangkan potensi lokal yang ada yaitu buah salak Bangkalan yang akan diolah sehingga dapat meningkatkan nilai tambah pada buah salak tersebut. Selain itu, pelatihan ini juga bertujuan untuk meningkatkan keterampilan para kelompok sasaran yaitu ibu-ibu rumah tangga dan para wanita muda dalam mengolah buah salak Bangkalan. Dengan keterampilan yang dimiliki nantinya diharapkan mereka dapat menjadikan produk olahan buah salak sebagai sebuah usaha. Dengan demikian, kesejahteraan masyarakat di Daerah Bangkalan akan meningkat dan diharapkan dapat mengurangi tingkat kemiskinan yang ada.

Kegiatan pengabdian kepada masyarakat ini juga turut mendukung program Pemkab Bangkalan yang sedang gencar mempromosikan buah Salak Bangkalan. Produk yang sudah pernah ada di Bangkalan yaitu kurma salak, keripik salak, sirup salak, manisan salak, kismis salak, dan sepatu dari kulit salak. Sehingga, kami mengadakan pelatihan pengolahan buah salak berupa produk yang belum pernah ada sebelumnya yaitu brownies salak, es krim salak, 
donat salak, dan kaligrafi dari kulit, biji serta daun salak sehingga buah salak dapat dimanfaatkan secara keseluruhan. Kegiatan ini akan memberikan manfaat jangka panjang jika peserta pelatihan nantinya terus meningkatkan inovasi dan kreativitas dalam pengolahan, pengemasan dan pemasaran produk (Nurhayati, 2020). Sejalan dengan pelatihan yang dilakukan Bone et al. (2015) untuk meningkatkan pengetahuan dan keterampilan kelompok wanita tani (KWT) kabupaten Malua dalam mengoperasikan, memelihara dan memperbaiki mesin produksi keripik salak, pengolahan salak menjadi produk lain dan memilih jenis kemasan sesuai dengan jenis dan kondisi produk, serta melakukan pengemasan produk yang tepat dan memiliki estetika yang tinggi.

\section{METODE PELAKSANAAN}

Teknik penyuluhan dalam pelatihan yang kami lakukan adalah dengan demo dan praktik langsung di setiap pelatihan. Hal ini dilakukan agar peserta pelatihan dapat dengan sepenuhnya menguasai keterampilan yang diajarkan. Kami mengadakan demo cara pembuatan produk kemudian peserta melakukan praktik langsung membuat produk.

Berdasarkan pelatihan yang dilakukan Diwanti \& Dharma (2019) metode pelaksanaan dilakukan dengan penyuluhan, pelatihan dan pendampingan kepada Warga dan mitra yakni lbu-lbu untuk memaksimalkan hasil dari rangkaian kegiatan. Sehingga pelaksanaan kegiatan pelatihan ini dilakukan melalui beberapa tahap yaitu: 1) Tahap sosialisasi kepada kelompok sasaran; 2) Tahap perolehan bahan dan alat; 3) Tahap pelatihan; 4) Tahap pendampingan serta 5) Tahap evaluasi kegiatan.

Ketercapaian pelaksanaan kegiatan ini dikatakan berhasil dilihat dari beberapa indikator, yaitu 1) sebanyak $75 \%$ peserta yang diundang hadir di setiap pelatihan dan indikator ini diukur dengan absensi di setiap pelatihan; 2) sebanyak $80 \%$ dari peserta yang hadir paham mengenai proses pengolahan buah salak menjadi donat, brownies, es krim, dan kaligrafi, kemudian indikator ini diukur dengan pengisian kuesioner dan observasi (pengamatan) ketika pelatihan; 3) sebanyak $25 \%$ dari peserta yang hadir menerapkan keterampilan tersebut menjadi usaha yang berkelanjutan dan indikator ini diukur dengan survei secara langsung pada masyarakat sasaran.

Pelatihan dibagi menjadi 2 gelombang. Pelatihan pertama untuk pelatihan pengolahan es krim salak dan brownies salak. Pelatihan yang kedua untuk mengolah donat salak dan kaligrafi salak. Target peserta sebanyak 25 orang yang terdiri dari ibu-ibu rumah tangga dan remaja wanita yang menikah di usia muda. Mereka terdiri dari lulusan SD hingga SMA.

\section{HASIL DAN PEMBAHASAN}

Hasil yang telah dicapai sesuai dengan luaran yang ditargetkan yaitu adanya keterampilan usaha untuk mengolah produk berbahan baku buah Salak Bangkalan yang belum pernah ada sebelumnya yaitu berupa donat salak, es krim salak, brownies salak, dan kaligrafi dari kulit salak.

Berdasarkan metode yang digunakan, hasil yang telah dicapai mencapai $100 \%$. Tahap pertama telah terlaksana yaitu sosialisasi kepada kelompok 
sasaran. Dalam rangka mengimplementasikan kegiatan pelatihan ini, langkah awal yang kami lakukan adalah melakukan pendekatan kepada kelompok sasaran melalui sosialisasi dari rumah ke rumah oleh tim. Hal ini dilakukan secara persuasif agar masyarakat Kampung Durinan khususnya ibu-ibu rumah tangga dan remaja perempuan putus sekolah yang menjadi target sasaran tertarik untuk mengikuti pelatihan tersebut tahap ini telah terlaksana secara keseluruhan dan memiliki persentase $10 \%$ dari total kegiatan. Bukti dokumentasi tahap pertama dapat dilihat pada Gambar 1.

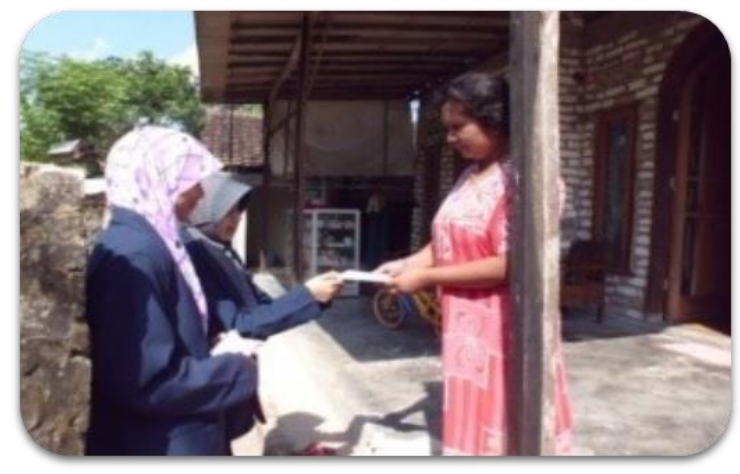

Gambar 1. Sosialisasi kepada masyarakat

Selanjutnya tahap kedua yaitu perolehan bahan dan alat telah terlaksana dengan lancar. Setelah melakukan sosialisasi kepada kelompok sasaran, kami mempersiapkan segala kebutuhan untuk pelatihan yaitu membeli alat-alat yang dibutuhkan beserta bahan bakunya. Untuk bahan baku utama berupa buah Salak Bangkalan, kami membeli langsung dari petani salak di daerah tersebut agar terjamin kesegaran dan kualitas rasanya. Tahap ini telah terlaksana secara keseluruhan dan memiliki persentase $10 \%$ dari total kegiatan.

Kemudian, untuk tahap ketiga yaitu kegiatan pelatihan yang telah terlaksana secara keseluruhan dan memiliki persentase $60 \%$ dari total kegiatan. Pada kegiatan pelatihan diadakan empat jenis pelatihan yang terbagi menjadi dua gelombang. Gelombang pertama untuk pelatihan pembuatan es krim salak dan brownies salak. Gelombang kedua untuk pelatihan pembuatan donat salak dan kaligrafi dari kulit salak.

Pelatihan Pembuatan es krim salak dilaksanakan pada gelombang pertama. Es krim salak merupakan es krim yang terbuat dari buah Salak Bangkalan yang bercita rasa asam, kecut, dan manis bercampur menjadi satu. Es krim salak merupakan salah satu inovasi baru dengan menambahkan bubuk es krim rasa vanila. Pelatihan pembuatan es krim salak diikuti oleh 22 peserta. Pelatihan pembuatan es krim salak dilaksanakan dengan cara demonstrasi. Para peserta diberikan buku resep pembuatan es krim salak dan mereka menyimak demonstrasi yang kami berikan. Pelatihan pembuatan es krim salak telah terlaksana secara keseluruhan dan memiliki persentase $15 \%$ dari total kegiatan pelatihan. Bukti dokumentasi pelatihan pembuatan es krim salak dapat dilihat pada Gambar 2. 


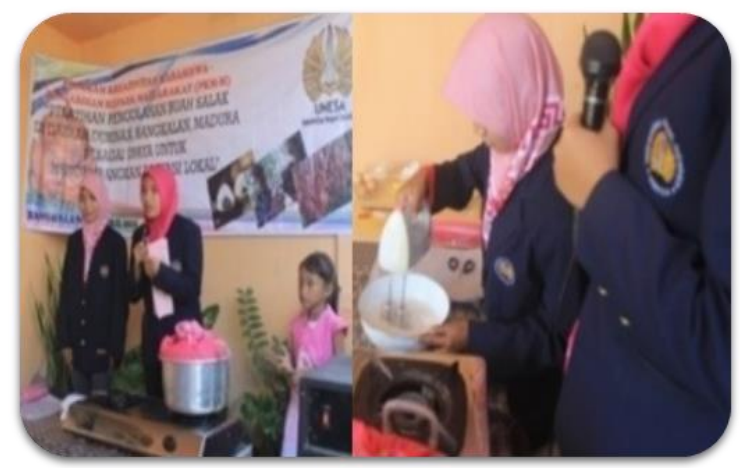

Gambar 2. Penjelasan dan demonstrasi pembuatan es krim salak

Pada gelombang pertama, juga diadakan pelatihan pembuatan brownies salak. Pelatihan pembuatan brownies salak juga dilaksanakan secara demonstrasi. Para peserta diberikan buku resep pembuatan brownies salak dan mereka menyimak demonstrasi yang kami berikan. Pelatihan pembuatan brownies salak telah terlaksana secara keseluruhan dan memiliki persentase $15 \%$ dari total kegiatan pelatihan. Brownies salak juga merupakan salah satu inovasi baru karena belum pernah ada brownies yang berbahan baku buah Salak Bangkalan yang bercita rasa asam. Berbeda dengan Salak Pondoh yang manis. Olahan brownies ini telah kami padukan dengan coklat serta untuk hiasan topingnya menggunakan irisan buah salak. Pelatihan pembuatan brownies salak diikuti oleh 22 peserta. Bukti dokumentasi untuk pelaksanaan pelatihan buah salak dapat dilihat pada Gambar 3.

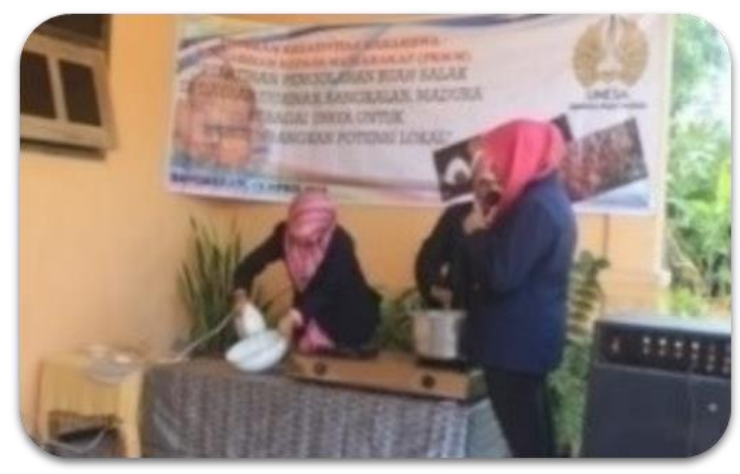

Gambar 3. Demonstrasi pembuatan brownies salak

Kemudian pada gelombang kedua, diadakan pelatihan pembuatan donat salak. Pelatihan pembuatan donat salak telah terlaksana secara keseluruhan dan memiliki persentase $15 \%$ dari total kegiatan pelatihan. Donat salak ini merupakan inovasi baru karena belum pernah ada sebelumnya. Adonannya berbahan baku salak dan isi donat berupa selai salak. Pelatihan pembuatan donat salak juga dilaksanakan secara demonstrasi. Para peserta diberikan buku resep pembuatan donat salak dan mereka menyimak demonstrasi yang kami berikan. Untuk hiasan diatasnya, kami memberikan kesempatan kepada 
peserta pelatihan untuk mengkreasikannya sendiri. Kemudian dilakukan pemberian hadiah bagi kelompok kreasi donat terbaik. Pelatihan pembuatan donat salak diikuti oleh 25 peserta. Bukti dokumentasi terlaksananya pelatihan pembuatan donat salak dapat dilihat pada Gambar 4.

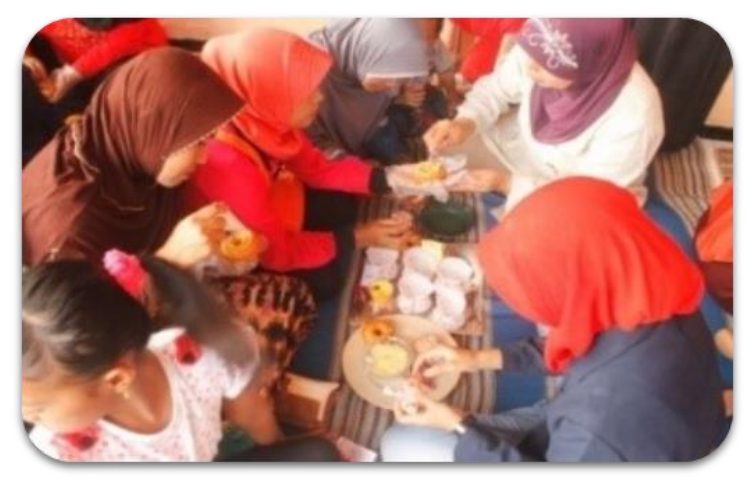

Gambar 4. Pelatihan pembuatan donat salak

Pembuatan Kaligrafi dari Kulit Salak juga diadakan pada gelombang kedua. Pelatihan pembuatan kaligrafi dari kulit salak telah terlaksana secara keseluruhan dan memiliki persentase $15 \%$ dari total kegiatan pelatihan. Setelah buah salak dimanfaatkan untuk membuat donat, brownies dan es krim, maka kulit salaknya dimanfaatkan sebagai bahan baku pembuatan kaligrafi yang belum pernah ada sebelumnya. Alasan kami memilih melakukan pelatihan pembuatan kaligrafi ini karena rata-rata masyarakat di Bangkalan cenderung religius. Selanjutnya, bijinya dimanfaatkan sebagai bingkai kaligrafi. Sehingga keseluruhan dari buah salak, mulai dari daging, biji dan kulitnya termanfaatkan dan tidak terbuang sia-sia. Kemudian, terdapat pemberian hadiah bagi kelompok pembuatan kaligrafi terbaik. Pelatihan pembuatan kaligrafi dari kulit salak diikuti oleh 25 peserta. Bukti dokumentasi terlaksananya pelatihan pembuatan kaligrafi dari kulit salak dapat dilihat pada Gambar 5.

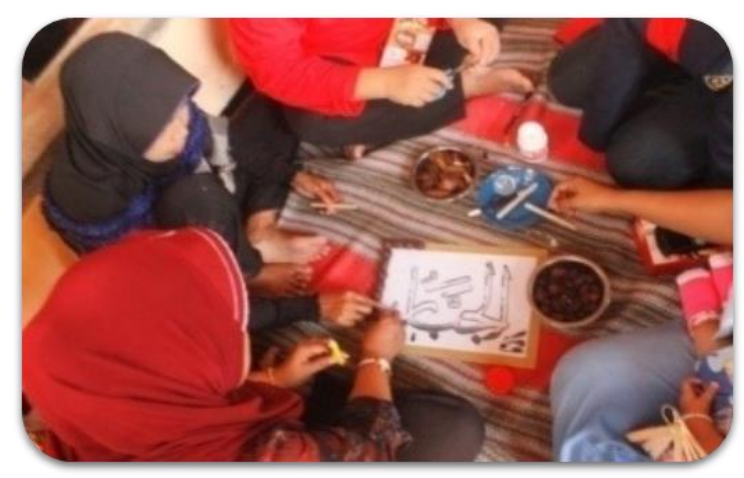

Gambar 5. Pelatihan pembuatan kaligrafi dari kulit salak

Setelah melakukan kegiatan pelatihan, tahap keempat yaitu melakukan pendampingan. Kegiatan kami tidak berhenti hanya hingga pelatihan 
pengolahan buah salak saja, tetapi kami juga telah membuka konsultasi bagi kelompok sasaran apabila terdapat kesulitan-kesulitan dalam mengimplementasikan keterampilan tersebut dalam kehidupan sehari-hari ataupun pada usaha mereka. Melalui berbagai pendekatan secara persuasif yang kami lakukan, tujuan untuk membantu kelompok sasaran kami harapkan dapat terwujud demi keberlangsungan usaha ini kedepannya. Selain memantau dan memotivasi kelompok sasaran, kami juga telah membantu dalam bidang pemasaran guna memajukan usaha yang telah ada. Untuk lebih lanjutnya, kami membantu kelompok sasaran untuk membuat sentra usaha olahan buah salak. Pendampingan ini telah terlaksana secara keseluruhan dan memiliki persentase $10 \%$ dari total kegiatan. Bukti dokumentasi terlaksananya pendampingan dapat dilihat pada Gambar 6.

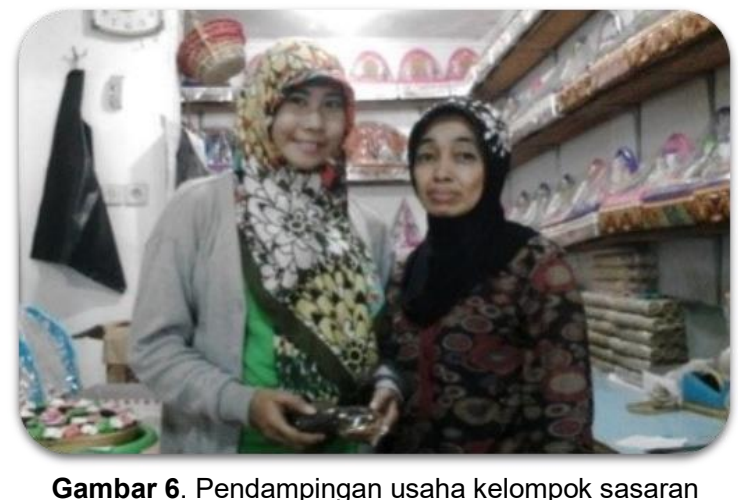

Selanjutnya yaitu tahap kelima yaitu evaluasi program yang telah terlaksana secara keseluruhan dan memiliki persentase $10 \%$ dari total kegiatan. Setelah melakukan keempat tahapan program, kami juga telah melaksanakan evaluasi program untuk melihat apakah ada perubahan atau tidak pada kelompok sasaran setelah diadakannya program pelatihan pengolahan buah salak. Ketercapaian pelaksanaan kegiatan ini dikatakan berhasil dilihat dari tiga indikator. Adapun indikator tersebut yaitu: 1) sebanyak $75 \%$ peserta yang diundang hadir di setiap pelatihan, indikator ini diukur dengan absensi di setiap pelatihan; 2) sebanyak $80 \%$ dari peserta yang hadir paham mengenai proses pengolahan buah salak menjadi donat, brownies, es krim, dan kaligrafi, kemudian indikator ini diukur dengan pengisian kuesioner dan observasi (pengamatan) ketika pelatihan; 3) sebanyak $25 \%$ dari peserta yang hadir menerapkan keterampilan tersebut menjadi usaha yang berkelanjutan dan indikator ini diukur dengan survei secara langsung pada masyarakat sasaran. 


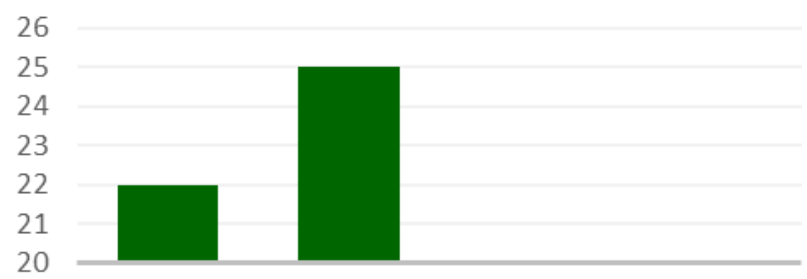

Gelombang 1 Gelombang 2

Kehadiran

Gambar 7. Diagram kehadiran peserta dalam mengikuti pelatihan

Berdasarkan Gambar 7, dapat dilihat bahwa pada pelatihan gelombang pertama, sebanyak 22 peserta dari total jumlah 25 peserta yang diundang hadir mengikuti pelatihan. Sehingga, persentase kehadiran peserta pada pelatihan gelombang pertama sebesar $88 \%$. Pada pelatihan gelombang kedua, semua peserta undangan yang berjumlah 25 orang hadir secara keseluruhan. Sehingga, persentase kehadiran peserta pada pelatihan gelombang kedua sebesar $100 \%$. Dengan demikian, target indikator pertama tercapai karena persentase kehadiran peserta lebih dari $75 \%$.

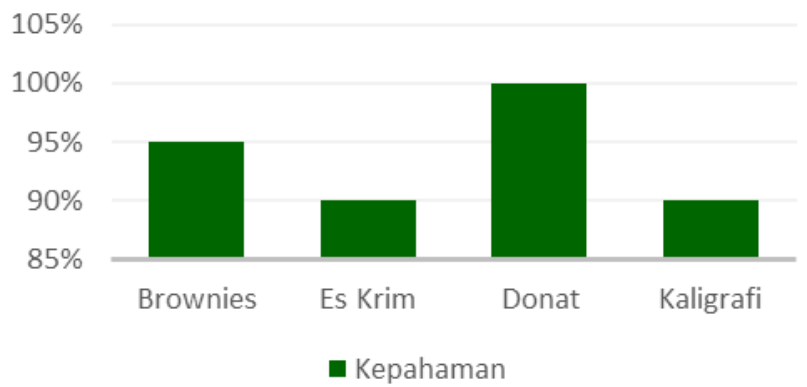

Gambar 8. Diagram tingkat kepahaman peserta

Berdasarkan Gambar 8, dapat dilihat bahwa sebanyak 95\% peserta pelatihan paham mengenai pembuatan brownies salak. Kemudian, untuk tingkat pemahaman pembuatan es krim salak sebesar $90 \%$. Selanjutnya, sebanyak $100 \%$ peserta pelatihan paham mengenai pembuatan donat salak. Kemudian, untuk pembuatan kaligrafi salak tingkat pemahaman peserta pelatihan sebesar $90 \%$. Dengan demikian, target pada indikator kedua tercapai karena peserta yang hadir paham mengenai proses pengolahan buah salak menjadi donat, brownies, es krim, dan kaligrafi lebih dari $80 \%$.

Selanjutnya, berdasarkan pendampingan yang telah dilakukan, kelompok sasaran yang menerapkan keterampilan dari pelatihan yang telah diberikan menjadi usaha sebanyak 8 orang dari 25 peserta yang hadir dengan presentase $32 \%$. Dengan demikian, target indikator ketiga tercapai karena lebih dari $25 \%$ dari peserta yang hadir menerapkan keterampilan tersebut menjadi usaha yang berkelanjutan. 
Potensi keberlanjutan dari pelatihan ini yaitu membuat sentra usaha produk olahan buah salak Bangkalan sehingga keterampilan yang telah dimiliki kelompok sasaran setelah mengikuti pelatihan dapat dikembangkan lagi. Sejalan dengan Rachman (2020) bahwa kegiatan pelatihan ini dapat meningkatkan pengetahuan dan keterampilan warga sehingga mampu meningkatkan daya saing produk unggulan berupa buah Salak Bangkalan. Selain itu, dengan adanya pelatihan pengolahan buah salak ini akan meningkatkan nilai tambah yang dimiliki. Upaya untuk mempertahankan mutu dan daya simpan buah salak adalah dengan cara mengolahnya menjadi produk olehan makanan (Dedin F Rosida et al., 2020).

Menurut Lubis et al. (2017) industri pengolahan salak memiliki prospek dan layak untuk dikembangkan lagi di masa yang akan datang. Dengan demikian, apabila sentra usaha produk olahan buah salak ini dapat berjalan dengan lancar, maka diharapkan nantinya dapat menjadi pusat oleh-oleh khas Bangkalan.

\section{KESIMPULAN}

Sebanyak $80 \%$ dari peserta yang hadir dalam pelatihan paham mengenai proses pengolahan buah salak menjadi donat, brownies, es krim, dan kaligrafi. Untuk pelatihan brownies salak, tingkat pemahaman peserta sebesar $95 \%$. Untuk pelatihan es krim salak, tingkat pemahaman peserta sebesar $90 \%$. Untuk pelatihan donat salak, tingkat pemahaman peserta sebesar $100 \%$. Kemudian untuk pelatihan kaligrafi salak, tingkat pemahaman peserta sebesar $90 \%$. Dengan demikian, dari keseluruhan pelatihan, peserta paling paham mengenai pembuatan donat salak. Berdasarkan pendampingan yang telah dilakukan, kelompok sasaran yang menerapkan keterampilan tersebut menjadi usaha sebanyak 8 orang dari 25 peserta dengan presentase $32 \%$.

\section{DAFTAR RUJUKAN}

Ahmad, U., Abrar, A., \& Punwadaria, H. K. (2001). Determination of Bruise Development Rate on Salak Fruit Using Image Processing. IFAC Proceedings Volumes, 34(11), 295-298. https://doi.org/10.1016/S14746670(17)34151-4

Bone, S., Fajar, H. R., \& Muchtar, N. (2015). Pengolahan dan Pengemasan Produk Olahan Salak di Kecamatan Malua Enrekang. Jurnal Teknologi

Elekterika, 12(1), 36-44. https://doi.org/10.31963/elekterika.v12i1.1500

Cahyani, U. E. (2017). Analisis Strategi Pengembangan Agribisnis Salak di Kabupaten Tapanuli Selatan. KOLEGIAL, 5(1), 36-50. http://journals.stiedwisakti.ac.id/ojs/index.php/kolegial/article/view/33

Diwanti, D. P., \& Dharma, A. F. (2019). Pengembangan Potensi Masyarakat Bangunmulyo melalui Program I-Createdi (Inovasi,Kreatif dan Mandiri) Home Industri Salak Pondoh. Martabe: Jurnal Pengabdian Kepada Masyarakat, 2(2), 62-66. https://doi.org/10.31604/JPM.V2I2.62-66

Hapsari, H., Djuwendah, E., \& Karyani, T. (2008). Peningkatan Nilai Tambah dan Strategi Pengembangan Usaha Pengolahan Salak Manonjaya. Agrikultura, 19(3), 208-215. 
https://doi.org/10.24198/AGRIKULTURA.V19I3.1005

Lubis, N., Siregar, S., \& Harahap, I. (2017). Prospek Pengembangan Industri Pengolahan Salak dalam Membangun Ekonomi Masyarakat Menurut Perspektif Islam (Studi Kasus Desa Parsalakan Kec. Angkola Barat Kab. Tapsel). FITRAH:Jurnal Kajian IImu-IImu Keislaman, 3(2), 277-298. https://doi.org/10.24952/fitrah.v3i2.774

Nurhayati, A. (2020). Pemberdayaan Ekonomi Masyarakat Kelompok Tani Salak Melalui Pelatihan Pengolahan Buah Salak di Desa Brambang Kecamatan Gondangwetan Kabupaten Pasuruan. SOEROPATI, 2(2), 127-140. https://doi.org/10.35891/JS.V2I2.2065

Rachman, Y. (2020). Aneka Olahan Sukun, Salak dan Daun Mangga Khas Kabupaten Bangkalan. Jurnal Ilmiah Pangabdhi, 6(1), 25-28. https://doi.org/10.21107/pangabdhi.v6i1.7482

Rosida, Dedin F, Syehan, B., Happyanto, D. C., Anggraeni, F. T., \& Hapsari, N. (2020). Keripik Salak Vacuum Frying sebagai Alternatif Pengembangan Produk Inovatif di Daerah Agroklimat Bangkalan Madura. Jurnal Layanan Masyarakat (Journal of Public Services), 4(1), 23-30. https://doi.org/10.20473/jlm.v4i1.2020.23-30

Rosida, Dedin Finatsiyatull, \& Taqwa, A. A. (2019). Kajian Pengembangan Produk Salak Senase (Salacca zalacca (Gaert.) Voss) Bangkalan Madura sebagai Permen Jelly. Jurnal Agroteknologi, 13(1), 62-74. https://doi.org/10.19184/j-agt.v13i01.10874

Setiawan, A. N., \& Dewi, S. S. (2016). Pemberdayaan Kelompok Aisyiyah dalam Pengelolaan Salak Pondoh di Kecamatan Turi, Sleman. Berdikari: Jurnal Inovasi Dan Penerapan Ipteks, 4(2), 63-72. https://doi.org/10.18196/BDR.427

Suarya, P., Sudiarta, I. W., Dewi Anggreni, A. M., Puspawati, N., \& Triani, I. L. (2007). Kursus Singkat dan Pelatihan Pengolahan Salak menjadi Dodol Salak di Desa Sibetan Kecamatan Bebandem Kabupaten Karangasem. Buletin Udayana Mengabdi, 6(2), 1-5. https://ojs.unud.ac.id/index.php/jum/article/view/1857

Triastuti, U. Y., \& Priyanti, E. (2017). Pelatihan Pengolahan Buah Salak untuk Meningkatkan Potensi Salak. TEKNOBUGA: Jurnal Teknologi Busana Dan Boga, 5(2), 24-33. https://doi.org/10.15294/teknobuga.v5i2.15367 